\title{
Highlighting on the Eco-tourism at Wadi Hammamat Site,Eastern Desert ,Egypt.
}

\author{
Abd El-Hakim A. El-BADRY
}

1 Manager of ARCE Laboratory Karnak, Ministry of Antiquities, Luxor, Egypt.

\begin{abstract}
The Wadi Hammamat site is one of the most important Rock art sites all over the world. It's contains different themes date back from the pre-dynastic periods until Islamic age. Also, the site was the main ancient quarry supplied the ancient Egyptian with the raw materials of stones and mines, which used for established the ancient civilization. The paper is highlighting the possibility of using Wadi Hammamat as an eco-tourism site, due to its proximity to the Red Sea coast area, this contributes to diversifying tourism and increasing the country's national income.
\end{abstract}

\section{Keywords}

Eco-tourism, Wadi Hammamat, Rock art, Petroglyphs, Pictographs, Site Management.

\section{1- INTRODUCTION}

Location : Wadi Hammamat is located about half way between Qusier (the port of Leukos Limen) on the Red Sea and Qift (ancient Coptos),in the Eastern Desert, Egypt (Fig.1-a) . The distance between Qift and Qusier is about $180 \mathrm{~km}$, sometime it was called Qift - Qusier road or Hammamat route between $\left(25^{\circ} 58.9^{\prime}\right.$ $\left.26^{\circ} 0.0^{\prime} \mathrm{N}\right)$ and $\left(33^{\circ} 33.8^{\prime}-33^{\circ} 34.6^{\prime} \mathrm{E}\right)$ (Harrell, et al.,1996). The route was used for millennia as a trade route from the Coast to the Nile, Not only the area was famed for its quarries and gold mines.; but also for remains of watchtowers, forts, wells and mines from various periods. Like the Roman watering station at Laghieta that is about 50km from the turnoff south of Qift, toll stations, and one of which, the Qasr el-Benat, the Castle of the Maidens, ( Fig.1-b) some of these remains are surviving today (Goyon, 1957 ).

\section{The Archaeological importance of Wadi Hammamat site:}

1-The site was midway of ancient and modern road (from River Nile to the Red Sea ) and it was part of the Silk Road that led to Asia or to Arabia and the horn of Africa ((The Silk Road or Silk Route refers to a historical network of interlinking trade routes across the Afro-Eurasian landmass that connected east, south, and western Asia with the Mediterranean and European world, as well as parts of north and east Africa. The land routes were supplemented by sea routes, which extended from the Red Sea to coastal India, China and Southeast Asia. extending 4,000 miles $(6,500 \mathrm{~km})$, the Silk road gets its name from the lucrative Chinese silk trade along it, which began during the Han dynasty (206 BCE - 220 BCE). The central Asian sections of the trade routes were expanded around 114 BCE by the Han dynasty (Fig.1-c).

2- Wadi Hammamat contains clastic sediments that were deposited into a Pan- African Orogeny molasses basin, contain a series siltstone, greywacke, to conglomerates, the name of Wadi Hammamat came from the halfworked tubs actually roman sarcophagi, abandoned at the site (Siddall, 2013) the site contains ancient quarry areas such as; variety of sandstone, greywacke and schist-type rocks which were all known as Bekhen-stone in ancient times (Shiah, 1942). The colors of the rocks vary from a very dark basalt-like stone, through reds, pinks 
and greens in addition to various geological structures (Fig.1-d) and extraction or quarrying marks.

3- The site contains more than six hundreds of hieroglyphic and hieratic rock inscriptions carved in the greywacke bedrock (Hikade, 2006), which record the activities of expeditions sent by several kings to obtain the precious resources of bekhen-stones, which were used for small-scale building projects, sarcophagi, statues and vessels during different periods of ancient Egyptian history.

4- It is also contains many gold- mines / work areas, the mining settlements and the abandoned British gold mine (dated back between 1930-1950s), owned by EMRA ( Bloxam, etal., 2015). Plus several stone tools such as; grooved stones, mill stones and stone morters, pottery and various unfinished objects such as GrecoRoman sarcophagi.

5- There is evidence in the area of prehistoric man, desert dwellers and nomads who left many petroglyphs and ancient Egyptian graffiti, into the rocks in the form of curved reed boats, hunters and long-gone animals, including elephants and ostriches, suggesting that the desert was at that time a more hospitable place.

6- The site contains writings in the hieratic, demotic script, where there are about 35 inscriptions in this line.

This is in addition to the hieroglyphic inscriptions Ptolemaic inscriptions, and Greek inscriptions, and there are about 120 inscriptions in the region, and Coptic and Arabic writings: accordingly, the area of Wadi ElHammamat can be considered "a linguistic complex from different ages".
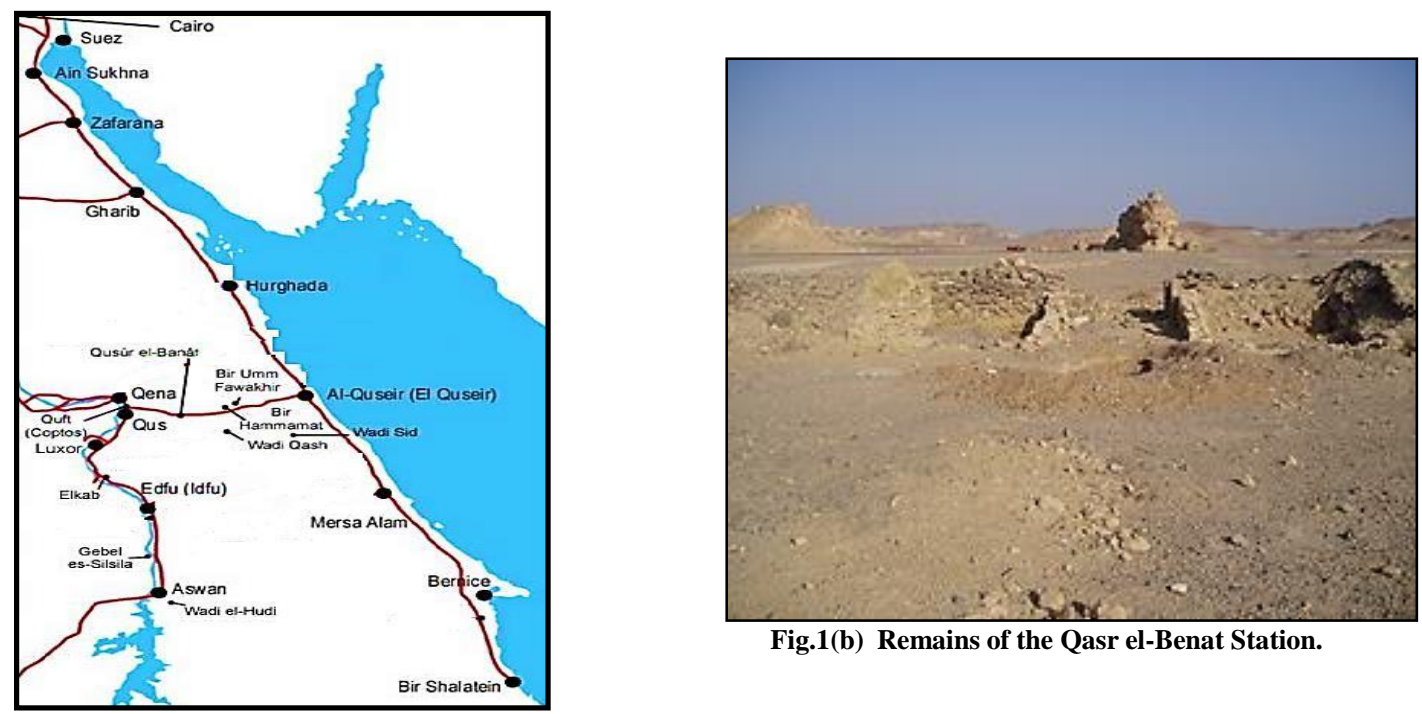

Fig.1(b) Remains of the Qasr el-Benat Station.

Fig. 1(a) Map Qift - Qusier road .

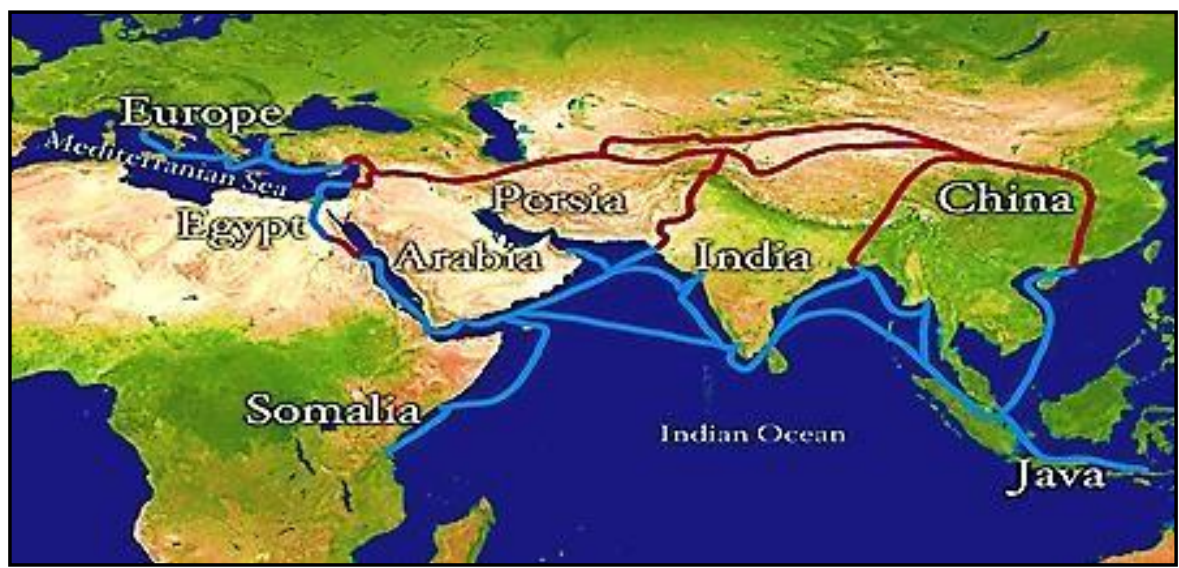

Fig.1(c) Map of ancient Silk road. 


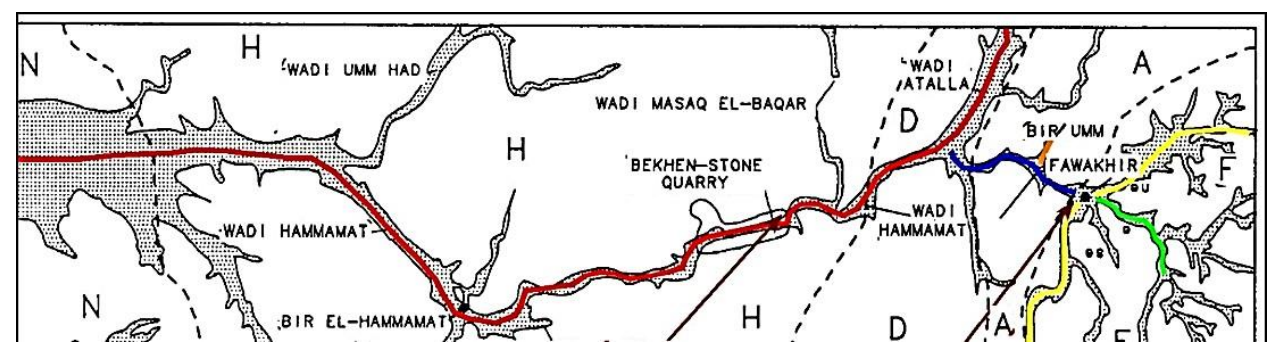

\section{2- ROCK ART THEMES AT WADI HAMMAMAT SITE:}

Rock art is considered the oldest form of art, it is divided into pictographs and petroglyphs applied on rock surfaces (Yates, etal.,1990)most of the rock art at Wadi Hammamat are petroglyphs, the previous study divides the themes of inscriptions at studied site to the following ( EL-Badry., 2008 );

\section{A- Predynastic Scenes : Which including both of :}

1- Human Scenes: representing different shapes of pre-historic man, very thin, the parts of body are not accurate ( Fig.2-a) also, there are several rock art of pre-dynastic boats (Redford. \& Redford.,1989) .

2- Animals Scenes : in addition to bulls and cows including caribou ,ostriches, gazelle, giraffes, antelope , deer(F.2-b) crocodile, fish, dog, wild rabbit, hippopotamus, lion and elephant, which are animals that live mostly in desert areas (Winkler, 1938 ). This may date back in rock art to the period between 8000-3600 BC. (Davis, 1978). It is clear from the animal scenes in rock art that some of the animals or birds that were depicted and that lived in those areas in the past have disappeared at the present time, and most of them no longer exist in those areas due to overhunting and climatic changes (Cherry, 2000) and archaeological evidence confirms that the wetted conditions have dominated Egypt during pre-dynastic times and that those areas, especially the eastern desert, were more abundant in the plants that helped the survival of those animals in them, which were drawn on the rocks. Perhaps there were some small lakes, stream or small canals that helped keep animals in those areas, which were depicted on the rock surfaces in those sites rather than being seen by artists along the Nile and then depicted on the rocks in those areas.

\section{B- Missions Inscriptions :}

There were a lot of missions which sent to the area by kings all over the Egyptian history for various purposes such as ;

\section{1- Quarrying Missions :}

At the Wadi Hammamat the quarrying of greywacke was an almost continuous operation from the Prehistoric (4th millennium BC) to the Roman time (4th cent $\mathrm{AD}$ ), which has left behind one of the world's largest sources of rock art. (Bloxam, etal.,2014) for extracting blocks of different stones such as; granite basalt, schist, sandstone, siltstone, bekhen-stone (especially meta-greywacke sandstone) for example; Senwosret I missions: record that he sent three missions in years 2, 26 and 38, the third of which was the largest ever to work in the Wadi. A team of roughly 18,660 skilled and unskilled workers (Fig.3-a), including soldiers, hunters, bakers and of course the scribes, artisans had the task of quarrying bekhen-stone for 60 sphinxes and 150 statues (Redford,2001). Two large rock-stelae date to this expedition. Later middle kingdom rulers attested here include Senusret II and III, each sending a single mission and Amenemhat III who sent at least four expeditions 
in years 2,3, and 20 in addition to mission led by led by Meri- Sheps from the year 19 of his reign( F.3-b), mentions that, he went with 2,000 soldiers to cut the stones needed to make some statues from the site (Couyat, et Montet , 1912).
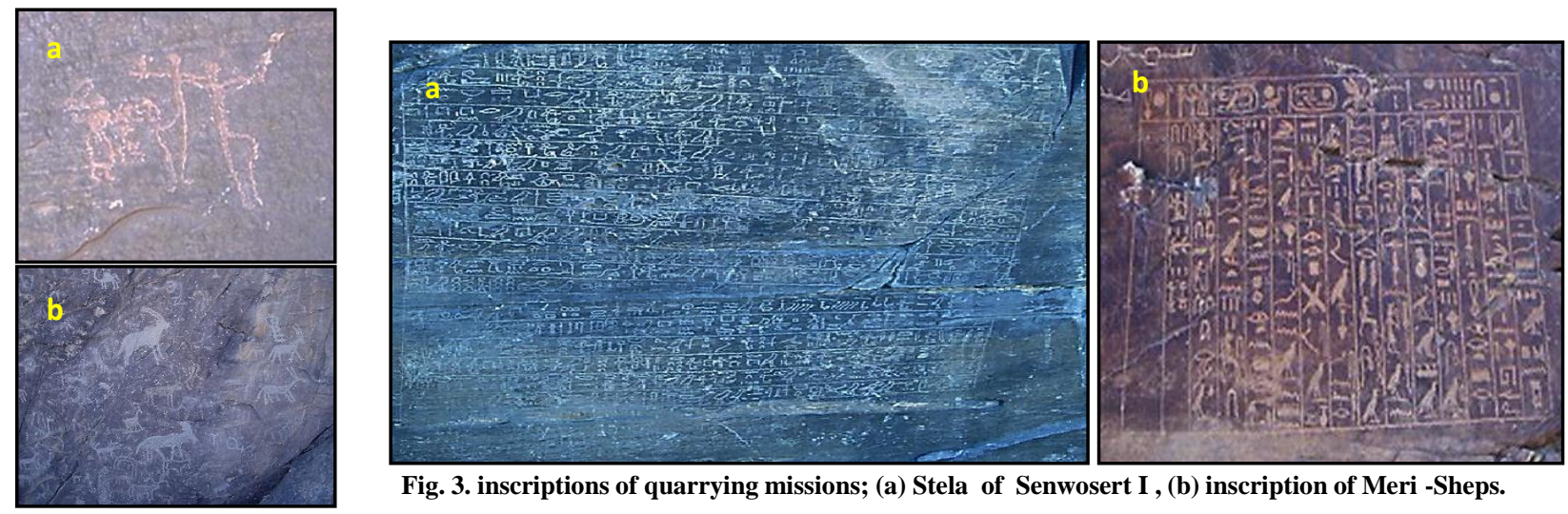

Fig.2(a ,b) Pre-dynastic rock art.

Fig. 3. inscriptions of quarrying missions; (a) Stela of Senwosert I , (b) inscription of Meri -Sheps.

\section{2- Mining Missions :}

Wadi Hammamat was used for extracting, copper, silver ,galena, tin, others precious metal-sand especially gold from Bir Umm Fawakhir, all over the history as noted from the inscriptions, modern and ancient geological maps, the latter is demonstrate from Turin Papyrus.

\section{Turin Papyrus:}

The oldest Egyptian geological map, records the largest expedition in the year 3 of the era of King Ramses IV, Dynasty 19 (the goal was to move the statue of Ramses from a quarry to a cemetery), It is drawn on a papyrus reportedly discovered at Deir el-Medina in Thebes, collected by Bernardino Drovetti in Egypt before 1824 AD and now preserved in Turin's Museo Egizio. The map was drawn about 1160 BC by the well-known Scribe-ofthe-tomb Amennakhte, son of Ipuy. With the aim of directing workers to the areas of quarries and mines. It recounted in detail the mountain road heading east from the Nile to the Red Sea through Wadi Hammamat. It showed the areas rich in gold mines and greywacke stone quarries in Wadi Hammamet, in addition to workers settlements and workshops at Bir Umm Fawakhir (Töpfer, 2018). It also includes numerous features, the destinations of the wadi routes, the distance between the quarry and mine, the location of gold deposits in the hills, and the sizes of the bekhen-stone blocks quarried (Fig.4 a-b). The inscriptions No. 23 (of Haqqa Ibb year 16) and No. 87 (of Amenemhat from the year 38) from the reign of king Senusret I; both mention a number of members of mining expeditions, including gold prospectors and goldsmiths are examples of mining missions inscriptions at the Wadi al-Hamamat site (Couyat, et Montet.,1912) .

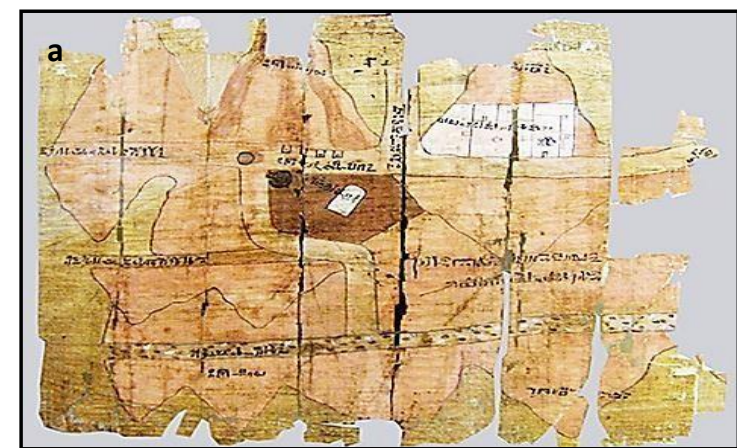

Fig.4(a). Map of The Turin Papyrus ( Wadi Hammamat site). nussimenseremess:

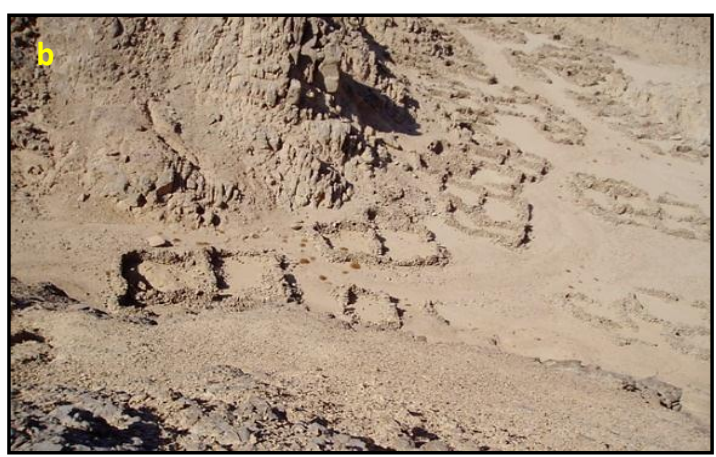

Fig.4(b). Workers settlement at Bir Umm Fawakhir. 
One of the important stela that mentioned the difficult conditions for working missions in this desert area is Rameses IV Stela ; The king sent numerous expeditions to the stone quarries of Wadi Hammamat, his great rock stela at the site records that, the largest expedition-dated to his year 3, third month of Shemu day 27- under the personal command of the high priest of Amun, Ramessesnakht. The original expedition consisted of 9,268 men and the mission back 8362 men, lost 900 men (Fig.5-a), this gives an indication of the harshness of life in Egypt's stone quarries. Some of the stones which were dragged 60 miles to the Nile from Wadi Hammamat weighed 40 tons or more.

\section{3- Trade Missions :}

Represented by the stela of Henenu (Fig.5-b ) that the king Mentuhotep III sent a large expedition of 3000 men in Year 8 of his reign, attested by a text of his chief steward Henenu, the purpose was to establish a trade contact with Punt, but they may also have done some quarrying ( Redford . \& Redford., 1989 ).

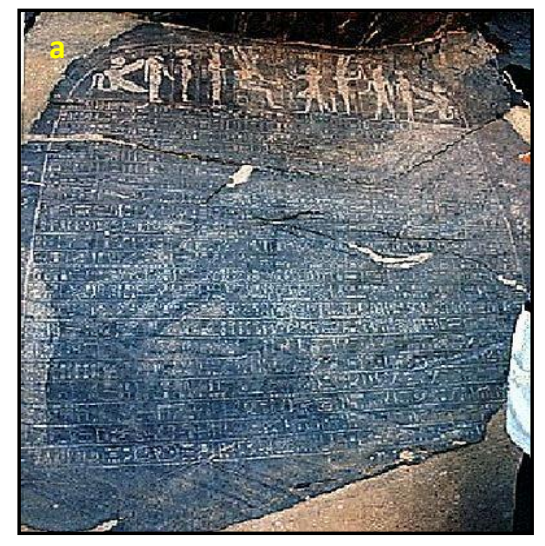

Fig.5(a). Stela of Rameses IV.

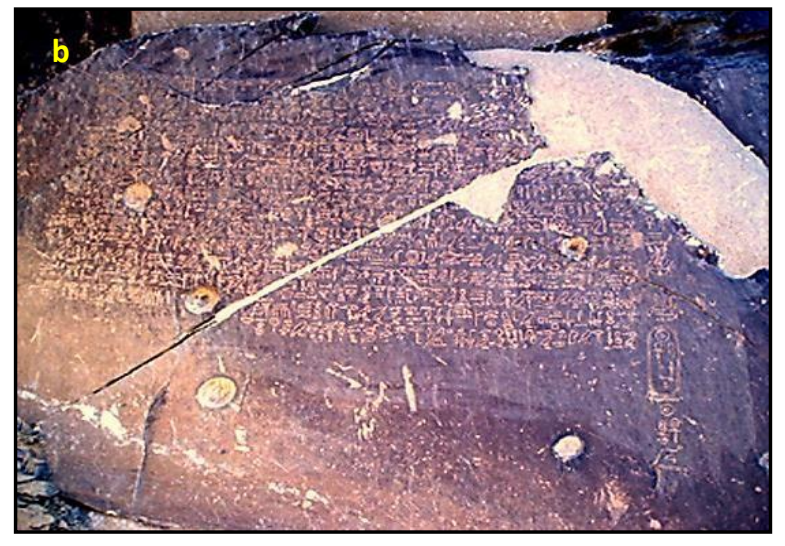

Fig.5(b). Stela of Henenu ( Trade Missions).

\section{4 -Hunting Missions:}

Many missions by the kings or nobles went to Wadi Hammamat for hunting the animals and birds like, stela of Sehankh (Fig.6-a) during the region of Mentuhotep II (11 dynasty) which records that, he went out with a number of his aides to hunt birds and bulls (Couyat, et Montet.,1912).Examples of hunting inscriptions from the Roman era include, the inscription no. 236 depicting a dog following a deer, and above it is a scene of a hunter on his horse, waving his spear and wearing a hat over his head. Under the horse we see the name of the hunter and this scene shows how to hunt deer (Goyon , 1957).

\section{5-Military Missions:}

These missions were to protect quarries, mines areas and for controlling the trade routes through the desert or both; some texts left by these missions at the site, like Greek graffiti by a solider named Julius (Fig.6-b).

\section{C-Royals Texts}

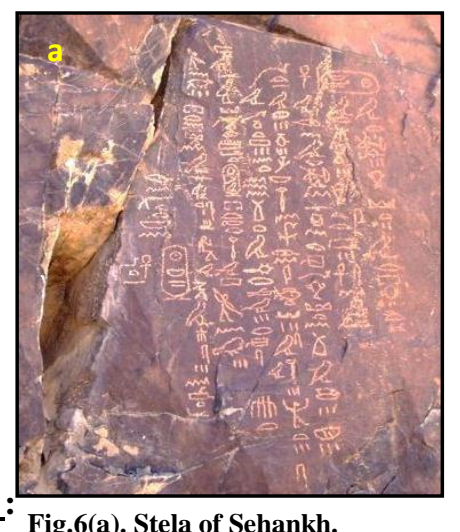

Fig.6(a). Stela of Sehankh.

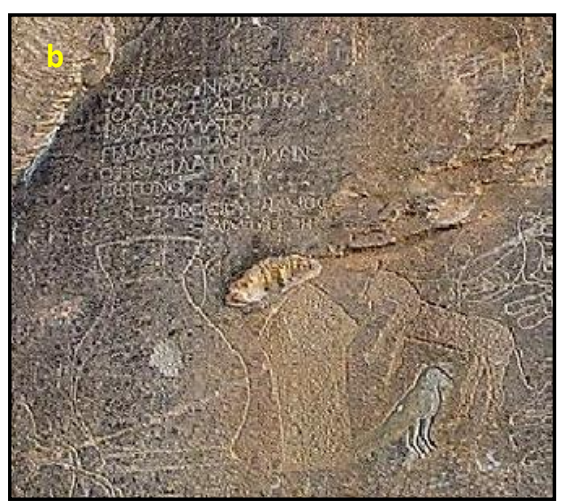

Fig.6 (b). The solider Juluis's text. 
In Wadi Hammamat there are a lot of cartouches and graffiti dating from early dynastic period until the Ptolemaic and Roman periods recorded different activities at the site for example;

\section{1- The Early dynastic period texts :}

Like graffito containing a serekh of the Early dynastic king Narmer, which is inscribed on a rock in the Wadi el-Qash, an offshoot of the Wadi Hammamat.

\section{2- The Old Kingdom texts :}

That can be dated with accuracy point to possibly several expeditions sent by Pepi I (who is represented in around 80 inscriptions), and an graffito also shows the presence of an expedition of Merenre, quarrying and military activities account for the majority of inscriptions from the Old Kingdom and the names of other kings briefly mentioned in graffiti and cartouches include Khufu, Khafre, Djedefre, Menkaure, Sahure, Unas, and. Djedkare Isesi (Fig.7(a-d)).

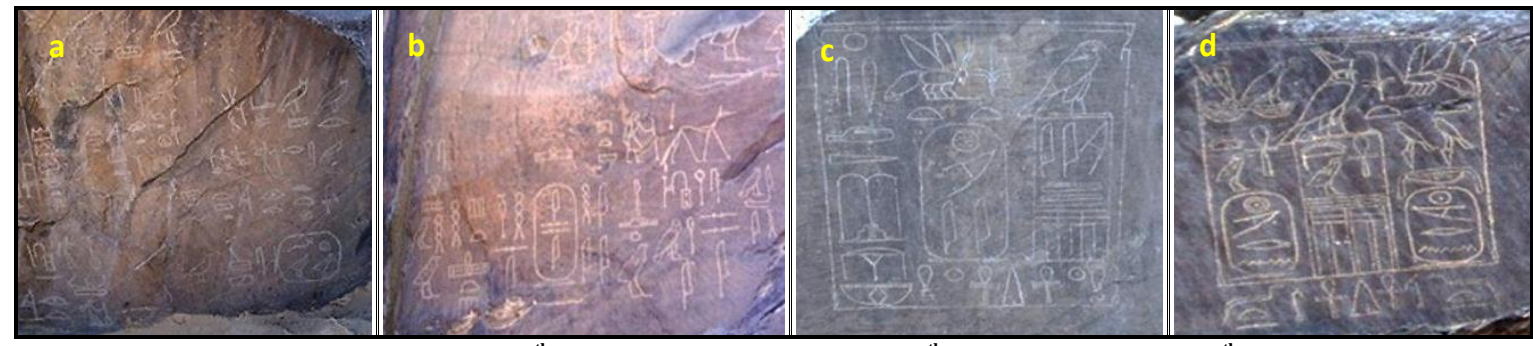

Fig.7. Cartouches of Kings; (a) Khufu $\left(4^{\text {th }}\right.$ dynasty) $\quad$ (b) Djedkare Isesi $\left(5^{\text {th }}\right.$ dynasty) $\quad$ (c) Pepi I $\left(6^{\text {th }}\right.$ dynasty) (d) Merenre $\left(6^{\text {th }}\right.$ dynasty $)$.

\section{3-The Middle Kingdom Texts :}

It seems to be Nebhepetre Mentuhotep II of dynasty XI who re-opened the Wadi Hammamat route and possibly sent quarrying expeditions there at the beginning of the Middle Kingdom and a short hieroglyphic graffito most probably dates to his age. Nebtawyre Mentuhotep IV sent an even larger expedition in year 2 of his reign, shown in four large rock-stelae. Amenemhat I, who left a single undated rock-stela in the Wadi Hammamat (Fig 8- a). Later middle Kingdom kings attested here include Senusret II \& III, each sending a single mission and Amenemhat III who sent at least four missions in years 2,3,19 and 20 of his time (Fig.8-b).

\section{4-The Second Intermediate Period :}

This period is represented in the Wadi Hammamat by a stele of Sobekhotep IV Khaneferre, while there was possibly two or three graffito naming king Sobekemsaf I, Sekhemre-wadjkhau.

\section{5-The New Kingdom period :}

Eighteen Dynasty; names and titles have recently been found representing Ahmose I (Fig.8-c) and Amenhotep II, but the two brief texts of Amenhotep IV (Akhenaten) found there are more interesting historically as they both mention a high priest of Amun who was sent to collect bekhen-stone. Probably this was from the king's early reign while the Theban priesthood was still in favour. Also; there are some cartouches with name of Thutmose III the Napoleon of Egypt left in the site on some rocky stela (Fig.8-d). Furthermore; during the nineteen dynasty Seti I reused a relief of Amenhotep IV, showing the king kneeling with two vases before Amun-re and two more images of Seti I have been found offering Ma'at and flowers to Amun-re (Fig.8-e). Seti II is also represented in a relief and a stela by the Vizier Paraemheb in which the king is in the presence of Min, Horus and Isis ( Fig.8(f-g) ). Rameses II is represented by only one set of cartouches in Wadi Hammamat (Fig.8-h) . At the time of twenty dynasty; stela inscribed by several priests and officials describe the expeditions 
of Rameses IV(Fig.8- i) and there are many minor graffiti dating to the reign. A text of Turu, high priest of Montu, dates to year 1 and depicts the king in the presence of many deities, while a stela dating to year 2 mentions the extracting of bekhen-stone for the 'place of eternity'.

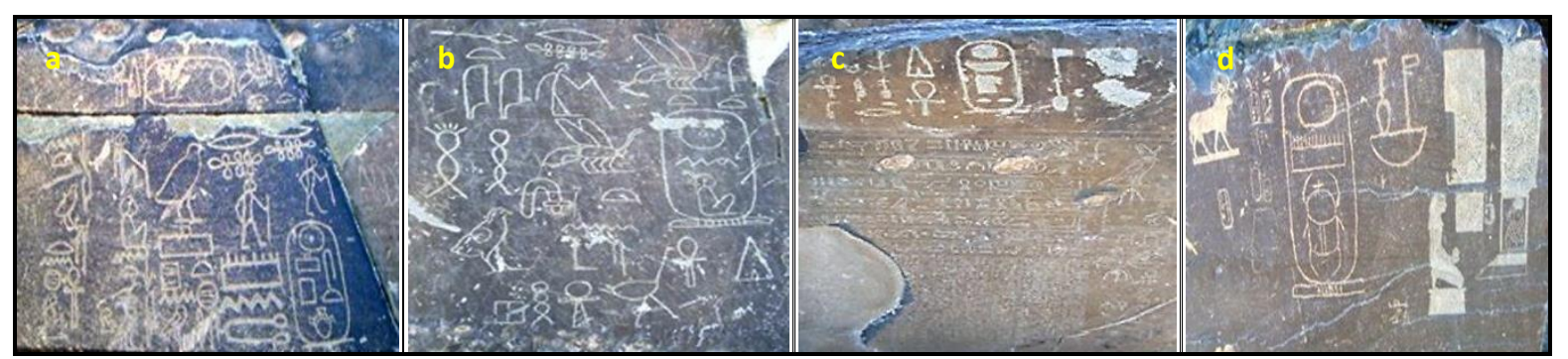

Fig.8. Texts of Kings; (a,b) Amenemhat I and Amenemhat III $\left(12^{\text {th }}\right.$ dynasty $),(c, d)$ Ahmose I and Thutmose III $\left(18^{\text {th }}\right.$ dynasty $)$.

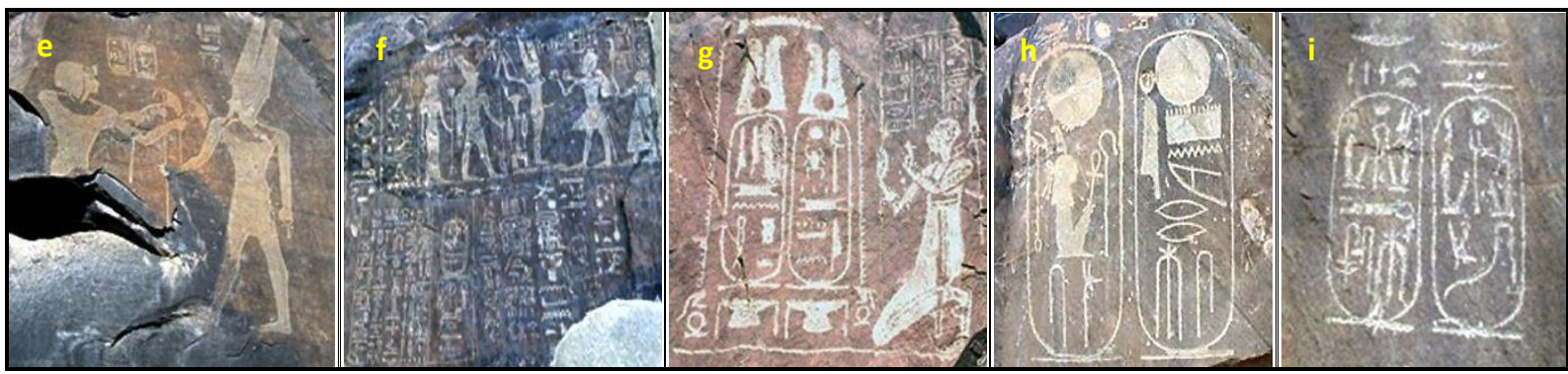

Fig.8 ( e-i) Texts of kings of Nineteen and Twenty dynasty at Wadi Hammamate site.

\section{6- Late Period :}

Many Cartouches and graffiti relating to Amenirdis I, King Shabaqo, Taharqa, Psamtek I, (Fig.9-a), Necho II and Psamtek II have also been found Graffiti dating to the First Persian Period occupation are particularly Numerous and seem to represent a new level of activity in the Wadi Hammamat. With the exception of Darius II, all of the major Persian kings are represented here. One very important graffito from this time was inscribed high on the sloping cliff-face by Khnemibre, who was a Royal Architect that held office during the reigns of Amasis and Darius I (Fig.9-b). Khnemibre himself is depicted standing before the goddess Hathor and the text is dated Year 26 of Darius. Also, there are several royal inscriptions dated back to the time of the twenty seven dynasty such as the cartouches of Xerxes I and Xerxes II (Fig.9-c). The latest hieroglyphic inscriptions in the Wadi Hammamat date to the reign of Nectanebo I and Nectanebo II of the Dynasty XXX (Fig.9-d), but there are also many demotic or Greek texts from the Ptolemaic and Roman Periods. The Romans brought renewed interest in the wadi, especially as a trading route, building watchtowers and signal posts, forts and a fortified well at Bir Hammamat. In the bekhen-stone quarries, a temple containing several side-chambers has been dated to the time of Tiberius by an inscribed naos. Graffiti in the Wadi record activity under Emperors Augustus, Nero, Titus, Domitian, Antoninus and Maximinus.

\section{7- Coptic and Islamic Graffiti:}

The site containing many graffiti some of them are Coptic while the other from Arabian and Islamic periods. Wadi Hammamat road used in antiquity by the merchants of Arabia to trade with the Egyptians. It was also part of the famous silk trade route with the Han Dynasty in China, it is also, considered part of the main road for trade and pilgrimage missions (Fig.9-e) to Mecca in Islamic times (Arthur, 1913).

\section{8-Modern Times graffiti :}


Wadi Hammamat site was visited by many famous archeologist, some of them left Graffiti by their names like Scot, James Bruce who traveled through the Wadi in 1769. The first extensive research on the site was done by the Russian Egyptologist Vladimir Golenischeff in the late 19th century. The Graffiti extend into the 20th century and the time of King Farouk, (Fig.9-f), who visited site during his trip to red sea coast in 1943

( Debono, 1951).

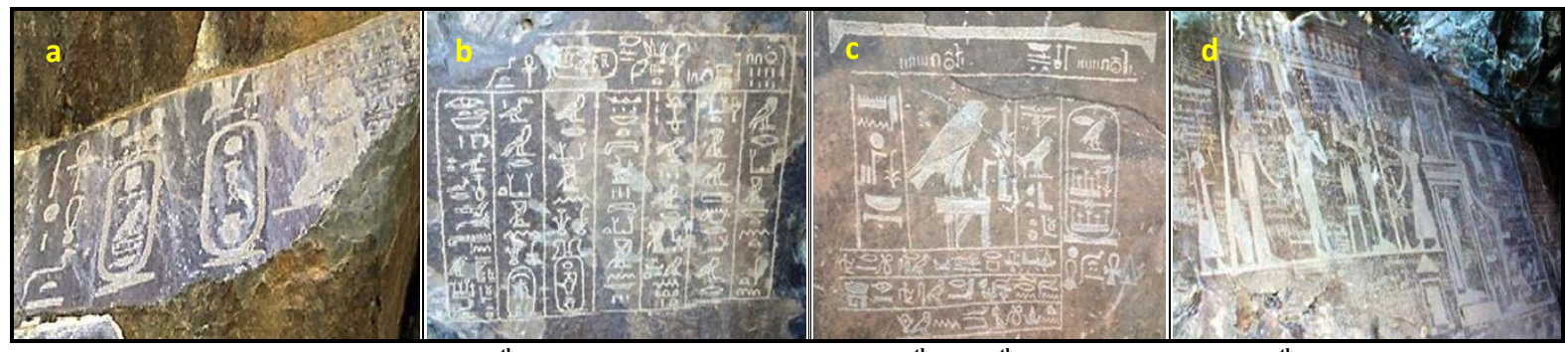

Fig. 9.Texts of Kings; (a) Psamtek I (26 $\left.{ }^{\text {th }} d y n\right)$, (b) Amasis and Darius I $\left(26^{\text {th }} \& 27^{\text {th }}\right.$ dyn $)$,(c) Xerxes II $\left(27^{\text {th }}\right.$ Dyn),

(d) Nectanebo I \&Nectanbo II ( $30^{\text {th }}$ Dyn).

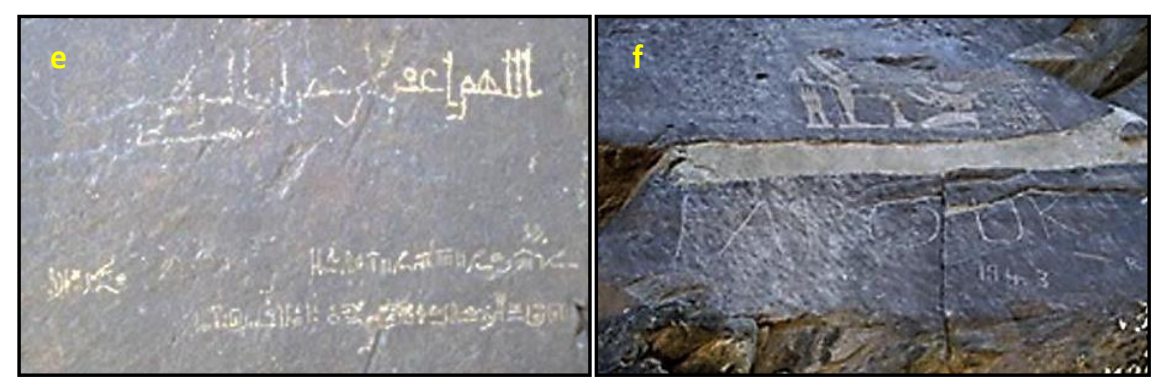

Fig. 9(e) Islamic Text (Kufic Line), (f) King Farouk signature on rock 1943.

\section{3-ECO-TOURISM REQUIREMENTS FOR THE WADI HAMMAMAT SITE}

Firstly; it's necessary to supply Wadi El- Hammamat site with department of conservation and maintenance, to treat the weaken rock art with appropriate chemicals and methods (El-Badry, etal.,2019) and monitoring the site. Prohibiting the touching, climbing and graffiti on the archaeological stones and rock art panels. Maximizing the guard works in the site to reduce the damage resulting from wrong human behaviour, thefts and robberies, the establishment of a department for crises and disasters at studied rock art site and the activation of its role ( EL- Badry 2019). Studied rock art, locates inside open - air site to the public, so controlling access is more difficult. So, it extensively demand site management strategy; such as the building of visitor's centre; provided with different attaches such as; restaurant, cafeteria, bookshop, bus parking, flying / air balloon, establishing physical and psychological barriers including low fences, pathways, and boardwalks and informative signage, guidance signs and interpretation panels ( Lambert, 2007). It's necessary to increase cultural and archaeological awareness of the importance of visiting the site and adding the site on the tourist map of Egypt. Todorov (1997) emphasized the importance of exploiting historical sites such as ancient mines \& quarries for the development of tourist areas, and Komoo (1997) added that natural cave areas or mining activities and rock extraction areas should be utilized, and the stones from their modern sites and the so-called in situ rock (stone) monuments, which are similar to the archaeological and historical sites, in order to develop a kind of ecotourism, and it is called the term "geology tourism" or "geology tourism" all of the above are available in the Wadi Hammamat region. 


\section{4-CONCLUSION}

Rock art plays a vital role in tourism in all over the world; Wadi El-Hammamat site is considered an ideal location for sustainable tourism development in Egypt so that;

- Rock art sites can become additional tourist destinations to Egypt's cultural and archaeological heritage and an additional source of national income for the country and reduce the rate of damage to rock sites, if they are managed well through the preparation of management plans, infrastructure in these sites.

- It is necessary to revive and activate the role of archaeological and historical facilities along the Qift - Qusier road, which include stations, water wells, old forts, and watchtowers and the others.

- Wadi El-Hammamat is located in the middle of the main road that connects the inhabitants of the Nile valley in the west and the inhabitants of the coastal areas on the Red Sea in the east on the other hand.

-The site contains many natural ingredients with cultural, cultural, historical, aesthetic, economic, geological, social and religious values of diverse tourism, which are represented in cultural tourism, historical tourism, geotourism (quarries and mines tourism) and scientific tourism. As well as having several caves, and shelters, Wadi Hammamat is an ideal place for adventure and geo-tourism.

- Exploitation of coastal areas near the Red Sea in activating many types of tourism, such as tourism of nature reserves, beaches tourism, recreational tourism, religious tourism, safari tourism and adventures, in addition to, tourism of traditional and folk crafts in the villages of the Red Sea Governorate.

\section{REFERENCES}

Abd El-Hakim A. EL- Badry., " Man-Made Deterioration of Karnak Temples Complex Past and Present: An Overview. " The $8^{\text {th }}$ International Conference and Strategic Planning Summit, Organized by World Alliance for Arts Education (WAAE), Luxor, 2019, pp.2699-2722.

Abd El-Hakim A. EL-Badry.," A Comparative Study for the Effect of the Weathering Processes on the Recording Rock Art ( Petroglyphs) in the Eastern \& Western Desert, and Methods of Treatment and Conservation, Applied on the Selected Site." Master Degree, Conservation dep. Faculty of archaeology, Cairo Uni,2008.

Abd El-Hakim A. El-Badry, Mona F.Ali, \& Badawi M. Ismail."Assessment of the Aging Treatments of Sandstone Greywacke Rock Art ( Wadi Hammamat) by Petrography, SEM, XRD, EDX ." SCIENTIFIC CULTURE, Vol. 5, No. 2, 2019., pp. 37- 48.

Arthur, E. P. W "Travels in The Upper Egyptian Deserts ." William Blackood \&Sons Edenburgh \&London, 1913, pp. 58-64.

Bloxam, E., Kelany,A. and Shaw,I. " Sixth archaeological survey of the ancient greywacke quarries of the Wadi Hammamat." Final Report to the Supreme Council of Antiquities, 2015, pp.1-5.

Bloxam,E., Harrell,J., Kelany,A., Moloney,N., El-Senussi A. \& Tohamey,A." Investigating the Predynastic origins of greywacke working in the Wadi Hammamat." ARCHÉO-NIL (Revue de la société pour l'étude des cultures prépharaoniques de la vallée du Nil), numéro24, Paris, 2014, pp.11-30.

Cherry , P." A Field Guide to the Fauna of the Eastern Desert ." The Followers of Hours "Eastern Desert Survey Report ", Institute for the Study of Interdisciplinary Scences ( ISIS) , Vol. 1, 2000, pp . 187-199.

Couyat , J. et Montet ,P. " Les Inscriptions Hieroglyphiques et Hieratiques du Ouadi Hammamat." Le Caire, 1912.

Davis , W.M." Dating Prehistoric Rock drawings in Upper Egypt and Nubia." Current Anthropology, Vol . 19, No,1 , 1978, pp . $216-217$.

Debono, F." Expédition archéologique royale au désert oriental (Keft -Kosseir). Rapport préliminare sur la campagne 1949." Annales du Service des Antiquitiés de l’Égypte 51, 1951,pp. 59-91. 
Goyon ,G . " Nouvelles Inscriptions Rupestres du Wadi Hammamat Ouvrage Puplie Avec Le Concours du Centere Nationale de la Recherche Scientifique." Imprimerie National, Libraririe d'Amerique, et d'Orient Adrien- Maisonneuve, Pairs, 1957,pp.1-18.

Harrell , J.A.,Brown,V.M.\& Masoud,M.S. " Survey of Ancient Egyptian Quarries." Egyptian Geological Survey and Mining Authority, Paper 72, 1996 , p. 17.

Hikade, T." Expeditions to the Wadi Hammamat during the New Kingdom. " The Journal of Egyptian Archaeology (JEA) 92, 2006, pp.153-168.

Komoo,I . "Conservation Geology: A case for the ecotourism industry of Malaysia. " Engineering Geology \& the Environment, Rotterdam,Vol.3, 1997, pp.2969 -2980.

Lambert, D., " Introduction to rock art conservation: a guide to the preservation of Aboriginal rock art." Department of Environment and Climate Change, Sydney South,2007.

Redford, B. D " The Oxford Encyclopedia of Ancient Egypt." The American University press in Cairo, Vol.1,2001.

Redford, S .\& Redford, B. D ." Graffiti and Petroglyphs Old \& New from The Eastern Desert." JARCE. $26,1989$.

Shiah, N." Some Remarks on The Bekhen stone ." A S A . 41,1942, pp. 199-205.

Siddall,R. " Geology in the British museum : The monumental stones of the eastern desert." UCL Earth Sciences, 2013.

Todorov, T. " Conservation of the geological heritage in Bulgaria: present state \& future initiatives. " Engineering Geology \& the Environment. Rotterdam, Vol.3, 1997,pp.3027 - 3032.

Töpfer,S." The Turin Papyrus Online Platform (TPOP): An Introduction." Rivista del Museo Egizio 2, 2018.

Winkler , A ., " Rock- Drawings of Southern Upper Egypt." London, 1938,pp. 17-18.

Yates, R., Parkington, J. and Manhire, T." Pictures from the past" Centaur, Pietermaritzburg, 1990. 